\title{
RAWLS' THEORY OF JUSTICE: AN ANALYSIS
}

\author{
Sampurnaa Dutta \\ Guest Lecturer, Department of Political Science, North Eastern Hill University, Shillong
}

\begin{abstract}
John Rawls was an American political philosopher in the liberal tradition whose theory of justice led to the revival of interest in political philosophy in modern times. In his celebrated work, A Theory of Justice, he asserted that a good society is characterised by a number of virtues. Justice is the first virtue of a good society. Though a seminal work in the discipline of Political Science, Rawls' theory has been criticised by various schools of thought. This paper makes an attempt to briefly study the theory of justice and make a critical analysis of the same. On a closer analysis, the diverse criticisms of Rawls' theory seem to be based on biased interpretations of his theory. In fact Rawls has tried to combine different value systems in order to arrive at his theory of justice. Some tenets of these value systems are thought to be mutually incompatible with each other. Indeed Rawls' theory of justice represents the convergence of libertarianism, egalitarianism and communitarianism.
\end{abstract}

\section{JOHN RAWLS: AN INTRODUCTION}

John Rawls was an American political philosopher in the liberal tradition whose theory of justice led to the revival of interest in political philosophy in modern times. Rawls himself developed his thinking in the liberal tradition, and followed the methodology of social contract-particularly John Locke's version of the theory-to arrive at the principles of justice. His theory of justice as fairness envisions a society of free citizens holding equal basic rights cooperating within an egalitarian economic system. His account of political liberalism addresses the legitimate use of political power in a democracy, aiming to show how enduring unity may be achieved despite the diversity of worldviews that free institutions allow. His writings on the law of peoples extend these theories to liberal foreign policy, with the goal of imagining how a peaceful and tolerant international order might be possible.

\section{THEORY OF JUSTICE}

John Rawls in his celebrated work A Theory of Justice asserted that a good society is characterised by a number of virtues. Justice is the first virtue of a good society. In other words, justice is necessary but not a sufficient condition of a good society. Those who argue that justice should not be allowed to come into the way of social advancement and progress run the risk of causing the moral degradation of society. In a just society, justice is established as the foundation of the social structure. Hence all political and legislative decisions should be designed to fulfill the requirements of justice.

\section{OBJECTIVE}

In A Theory of Justice, Rawls argues for a principled reconciliation of liberty and equality. Central to this effort is an account of the circumstances of justice, inspired by David Hume, and a fair choice situation for parties facing such circumstances, similar to some of Immanuel Kant's views. Principles of justice are sought to guide the conduct of the parties. These parties are recognized to face moderate scarcity, and they are neither naturally altruistic nor purely egoistic. They have ends which they seek to advance, but prefer to advance them through cooperation with others on mutually acceptable terms. Rawls offers a model of a fair choice situation (the original position with its veil of ignorance) within which parties would hypothetically choose mutually acceptable principles of justice. Under such constraints, Rawls believes that parties would find his favoured principles of justice to be especially attractive, winning out over varied alternatives, including utilitarian and rightlibertarian accounts. 


\section{THE ORIGINAL POSITION}

Rawls sets out his theory by placing individuals abstracted from their social and economic contexts behind what he calls the 'veil of ignorance'. Perhaps the most influential idea of Rawls's Theory of Justice is the famous thought experiment he called the "original position." The intuition motivating its employment is this: the enterprise of political philosophy will be greatly benefited by a specification of the correct standpoint a person should take in his or her thinking about justice. When we think about what it would mean for a just state of affairs to obtain between persons, we eliminate certain features (such as hair or eye color, height, race, etc.) and fixate upon others. Rawls's original position is meant to encode all of our intuitions about which features are relevant, and which irrelevant, for the purposes of deliberating well about justice.

The original position is a hypothetical scenario in which a group of persons is set the task of reaching an agreement about the political and economic structure of a society which they are, once an agreement has been reached, to occupy. Each individual, however, deliberates behind a "veil of ignorance." Each lacks knowledge, for example, of his or her gender, race, age, intelligence, wealth, skills, education, and religion. The only thing a given member knows about himself is that he is in possession of the basic capacities necessary for him to fully and willfully participate in an enduring system of mutual cooperation; each knows he can be a member of society. Rawls believes there are two such basic capacities which the individuals know themselves to possess. First, each individual knows that he has the capacity to form, pursue, and revise a conception of the good, or life plan. Exactly what sort of conception of the good this is, however, the individual does not know. It may be, for example, religious or secular, but the individual in the original position does not know which.

Second, each individual understands himself to have the capacity to develop a sense of justice and a generally effective desire to abide by it.

Knowing only these two features of himself/herself, each individual will deliberate in order to design a social structure that will secure herself maximal advantage. The idea is that proposals we would ordinarily think of as unjust - such as that blacks or women should not be allowed to hold public office - will not be proposed in the original position because it would be irrational to propose them. Rawls also assumes that these hypothetical people would be conservative risk takers and in a situation of uncertainty would obviously opt for the least disadvantageous outcome in any choice presented to them. Hence, they would choose those principles which would maximize the position of the worst-off, assuming that when the veil is removed, they themselves would turn out to be the worst-off.

\section{THE TWO PRINCIPLES OF JUSTICE}

Rawls expressed his ideas of justice as fairness in his two principles of justice:

\section{- First Principle:}

Each person has the same indefeasible claim to a fully adequate scheme of equal basic liberties, which scheme is compatible with the same scheme of liberties for all;

\section{- Second Principle:}

Social and economic inequalities are to satisfy two conditions:

a. They are to be attached to offices and positions open to all under conditions of fair equality of opportunity;

b. They are to be to the greatest benefit of the least-advantaged members of society (the difference principle).

The first principle of equal basic liberties is to be used for designing the political constitution, while the second principle applies primarily to economic institutions. Fulfillment of the first principle takes priority over fulfillment of the second principle, and within the second principle fair equality of opportunity takes priority over the difference principle. The first principle affirms for all citizens familiar basic rights and liberties: liberty of conscience and freedom of association, freedom of speech and liberty of the person, the rights to vote, to hold public office, to be treated in accordance with the rule of law, and so on. The principle ascribes these rights and liberties to all citizens equally. Unequal rights would not benefit those who would get a lesser share of rights, so justice requires equal rights for all in all normal circumstances. 
Rawls's first principle accords with widespread convictions about the importance of equal basic rights and liberties. Two further features make this first principle distinctive. First is its priority: the basic rights and liberties must not be traded off against other social goods. The first principle disallows, for instance, a policy that would give draft exemptions to college students on the grounds that educated civilians will increase economic growth. The draft is a drastic infringement on basic liberties, and if a draft is implemented then all who are able to serve must be equally subject to it.

The second distinctive feature of Rawls's first principle is that it requires fair value of the political liberties. The political liberties are a subset of the basic liberties, concerned with the rights to hold public office, the right to affect the outcome of national elections and so on. For these liberties Rawls requires that citizens be not only formally but also substantively equal. That is, citizens similarly endowed and motivated should have the same opportunities to hold office, to influence elections, and so on regardless of their social class. This fair value proviso has major implications for how elections should be funded and run, as described below.

Rawls's second principle of justice has two parts. The first part, fair equality of opportunity, requires that citizens with the same talents and willingness to use them have the same educational and economic opportunities regardless of whether they were born rich or poor. So for example if we assume that natural endowments and willingness are evenly distributed across children born into different social classes, then within any type of occupation we should find that roughly one quarter of people in that occupation were born into the top $25 \%$ of the income distribution, one quarter were born into the second-highest $25 \%$ of the income distribution, one quarter were born into the secondlowest $25 \%$, and one-quarter were born into the lowest $25 \%$. Since class of origin is a morally arbitrary fact about citizens, justice does not allow class of origin to turn into unequal real opportunities for education or meaningful work.

The second part of the second principle is the difference principle, which regulates the distribution of wealth and income. With these goods inequalities can produce a greater total product: higher wages can cover the costs of training and education, for example, and can provide incentives to fill jobs that are more in demand. The difference principle requires that social institutions be arranged so that any inequalities of wealth and income work to the advantage of those who will be worst off. The difference principle requires, that is, that financial inequalities be to everyone's advantage, and specifically to the greatest advantage of those advantaged least.

\section{A CRITICAL APPRAISAL}

Rawls' theory of justice has been criticised by various schools of thoughts.

In 1974, Robert Nozick, published a defense of libertarian justice, Anarchy, State, and Utopia. Michael Walzer, wrote a defense of communitarian political philosophy, Spheres of Justice, as a result of a seminar he co-taught with Nozick. In a related line of criticism, Michael Sandel wrote Liberalism and the Limits of Justice, which criticized A Theory of Justice for asking us to think about justice while divorced from the values and aspirations that define who we are as persons, and which allow us to determine what justice is.

Collectivists argue that Rawls has discovered the ground for the justification of the existing capitalist system. He has shown that if the rich have the freedom to accumulate wealth, the poor would be automatically benefitted. Even if his principle of fair equality of opportunity is strictly enforced, the existing disparities between the rich and poor will not be substantially reduced. A slight improvement in the condition of the most disadvantaged sections will be treated as an excuse to permit vast socio-economic inequalities.

Robert Paul Wolff wrote Understanding Rawls: A Critique and Reconstruction of A Theory of Justice, which criticized Rawls from a Marxist perspective. Wolff argues in this work that Rawls' theory is an apology for the status quo insofar as it constructs justice from existing practice and forecloses the possibility that there may be problems of injustice embedded in capitalist social relations, private property or the market economy.

Feminist critics of Rawls, such as Susan Moller Okin, largely focused on weakness of Rawls' in accounting for the injustices and hierarchies embedded in familial relations. Rawls argued that justice ought only to apply to the basic structure of society. Feminists, rallying around the theme of "the personal is political," took Rawls to task for failing to account for injustices found in patriarchal 
social relations and the gendered division of labor, especially in the household. Some egalitarian critics have raised concerns over Rawls' emphasis on primary social goods. For instance, Amartya Sen has argued that we should attend not only to the distribution of primary goods, but also how effectively people are able to use those goods to pursue their ends. Amartya Sen, a former student of Rawls', critiques and attempts to revitalize A Theory of Justice in his 2009 book The Idea of Justice. He credits Rawls for revitalizing the interest in the ideas of what justice means and the stress put on fairness, objectivity, equality of opportunity, removal of poverty, and freedom. However, Sen, as part of his general critique of the contractarian tradition, states that ideas about a perfectly just world do not help redress actual existing inequality. Sen faults Rawls for an over-emphasis on institutions as guarantors of justice not considering the effects of human behaviour on the institutions' ability to maintain a just society. Sen believes Rawls understates the difficulty in getting everyone in society to adhere to the norms of a just society. Sen also claims that Rawls position that there be only possible outcome of the reflective equilibrium behind the veil of ignorance is misguided. Sen believes that multiple conflicting but just principles may arise and that this undermines the multi-step processes that Rawls laid out as leading to a perfectly just society.

\section{CONCLUSION}

On a closer analysis, the diverse criticisms of Rawls' theory seem to be based on biased interpretations of his theory. In fact Rawls has tried to combine different value systems in order to arrive at his theory of justice. Some tenets of these value systems are thought to be mutually incompatible with each other. Indeed Rawls' theory of justice represents the convergence of libertarianism, egalitarianism and communitarianism. In the first place, Rawls is a libertarian because his conception of men negotiating in the original position envisages a situation where each of them is trying to maximize his self interest. This conforms to the libertarian point of view. Secondly, his first principle of justice accords priority to liberty which cannot be compromised for any other benefit.

Then Rawls is an egalitarian because he concedes equal liberty for all. Further, he insists that socioeconomic inequalities can be allowed only if they satisfy the condition of fair equality for all. Again, he rules that any reward for merit and effort must satisfy the condition that yields greatest benefit to the least advantaged. Why should the meritorious accommodate the interests of the least advantaged? Here Rawls invokes the principle of the 'chain connection' operating between different individuals. He shows that society can be strengthened by strengthening its weakest parts successively. The idea of chain connection brings Rawls very close to the image of a communitarian. In his more recent writings Rawls seems especially concerned with the problem of assuring political stability in a pluralist or multicultural social environment. Rawls gives this current preoccupation-and his new theory of justice-its most complete elaboration in his second book, Political Liberalism.

\section{REFERENCES}

[1] Political Theory An Introduction, Edited by Rajeev Bhargava and Ashok Acharya, First Edition, (2008) Pearson Publication

[2] Political Thinkers From Socrates to the Present, Edited by David Boucher and Paul Kelly, (2009) Oxford University Press

[3] Western Political Thought, O P Gauba, (2011) Laxmi Publications

[4] An Introduction to Political Theory, O P Gauba, (2014) Macmillan Publishers India Ltd

[5] Stanford Encyclopedia of Philosophy 